Цей процес вимагає тривалого часу і передбачає не тільки написання конспекту заняття, а й психологічну підготовку до його проведення, глибоке осмислення мети заняття, зміст основних етапів і положень, власне творче бачення дисципліни, усвідомлення іiі значущості, впевненості у своїх знаннях; оволодіння майстерністю виступу й діалогічною взаємодією з аудиторією.

Слід підкреслити, що від якості організації практичної діяльності студентів залежить реалізація основного завдання в тенденції модернізації освіти - активізувати мотивацію діяльності в ході вивчення навчальних дисциплін, формувати в майбутніх фахівців самостійне, креативне й професійне мислення, динамізувати потребу у творчій педагогічній діяльності, забезпечуючи цим самим високий рівень сформованості професійно-особистісного досвіду.

Отже, діяльнісно-практичний компонент професійно-особистісного досвіду, як і процес його формування в майбутніх учителів музики, слід розглядати як досить специфічну i складноструктуровану систему, що охоплює різноманітні елементи та їх функціональні взаємозв'язки, які вимагають обгрунтованого визначення і теоретичного моделювання, а також віднаходження системоутворювальних чинників для педагогічного управління процесами його формування та розвитку.

\title{
Література
}

1. Архангельский С. И. Учебный процесс в высшей школе, его закономерные основы и методы / С. И. Архангельский. - М. : Высшая школа, 1980. - 384 с. 2. Білоус О. С. Формування творчої активності студентів у процесі навчання предметам музичного циклу / О. С. Білоус // Науковий часопис Національного педагогічного університету імені М. П. Драгоманова. - Серія 16: Творча особистість учителя: проблеми теорії і практики: [зб. наук. праць] / ред. кол.: О. Г. Мороз, Н. В. Гузій. - Вип. 2 (12). - К. : НПУ, 2004. - С. 59-62. 3. Брушлинский А. В. Субъект: мышление, учение, воображение: Избранные психологические труды. - М. : Ин-т практической психологии, 1996. - 390 с. 4. Вербицкий А. А. Активное обучение в высшей школе: контекстный подход / А. А. Вербицкий. М.: Высшая школа, 1991. - 206 с. 5. Выготский Л. С. Педагогическая психология. - М. : ПедагогикаПресс, 1996. - 536 с. 6. Леонтьев А. Н. Избранные психологические произведения: В 2-х т. / под ред. В. В. Давыдова. - Т. 2. - М. : Педагогика, 1983. - 318 с. 7. Рубинштейн С. Л. Основы общей психологии: В 2 т. Т.2 - М. : Педагогика, 1989. - 324 с.

УДК $371.132+371.134: 373.3$

I. В. Размолодчикова, кандидат пед. наук, ст. викладач, Криворізький педагогічний інститут ДВНЗ «Криворізький національний університет»

\section{ВПЛИВ ЦІННССИХ ОРІЄНТАЦІЙ НА ФОРМУВАННЯ ІМІДЖУ МАЙБУТНЬОГО ВЧИТЕЛЯ}

Размолодчикова I. В. Вплив ціннісних орієнтацій на формування іміджу майбутнього вчителя.

У статті здійснено спробу проаналізувати вплив ціннісних орієнтацій на формування та розвиток особистості сучасного вчителя початкових класів.

Ключові слова: учитель, саморозвиток, ціннісні орієнтації, професійно-педагогічні цінності, культура, самовдосконалення.

Размолодчикова И. В. Влияние ценностных ориентаций на формирование имиджа будущего учителя.

В статье проанализировано влияние ценностных ориентаций на формирование и развитие личности современного учителя начальных классов.

Ключевые слова: учитель, саморазвитие, ценностные ориентации, профессиональнопедагогические ценности, культура, самосовершенствование.

Razmolodchikova I. V. The influence of value orientations to formation of image of future teacher. 
In this article authors attempt to analyze the impact of value orientations on the formation and development of personality of modern primary school teacher.

Key words: teacher, self-development, value orientations, professional pedagogic values, culture, selfperfection.

Проблема професіоналізму вчителя, його світоглядної культури, духовно-моральних переконань - одна 3 найактуальніших у педагогіці та філософії освіти. Саме від особистісних характеристик педагога залежить реалізація навчальних планів, якість освітніх послуг, виховання учнів як у процесі навчання, так і в позанавчальний час.

У Національній доктрині розвитку освіти України у XXI столітті, у Державній програмі «Вчитель» визначаються завдання формування особистості вчителя відповідно до потреб практики, сучасних змін, що відбуваються в країні та світі. Цей процес має бути забезпечений теоретично, тому дослідження проблеми формування особистості сучасного вчителя, його іміджу є актуальним і невідкладним завданням.

Mema cmammi - проаналізувати проблему формування ціннісних орієнтацій особистості сучасного вчителя, його іміджу відповідно до сучасної практичної діяльності.

В українській педагогічній літературі останніх років до проблеми формування особистості сучасного вчителя зверталися такі науковці, як В. Андрущенко, С. Гончаренко, М. Євтух, I. Зязюн, В. Кремень, В. Кушерець, О. Савченко, О. Сердюк, I. Надольний, В. Огнев'юк та ін. Проблемою іміджу сучасного вчителя опікуються О. Абдулліна, Р. Арнхейм, П. Берд, Н. Кузьміна, В. Ліпман, В. Орєшкін, Н. Черепанова, В. Шепель та ін.

У філософській, психолого-педагогічній науковій літературі (праці В. Водзинської, А. Здравомислова, В. Ольшанського, Є. Соколова, Л. Фоміної, В. Цукермана, В. Ядова та ін.) ціннісні орієнтації розглядаються як відносно стійка система цінностей, що виражається у здатності суб'єкта до цілісного переживання, усвідомлення явища або предмета й здійснення вибіркової оцінної діяльності.

У психологічно-педагогічній літературі проблема ціннісних орієнтацій особистості висвітлюється в працях відомих вітчизняних психологів: Б. Ананьєва, А. Бодалєва, Л. Виготського, О. Леонтьєва, В. Мясищева, С. Рубінштейна, Д. Узнадзе. Певні важливі висновки щодо проблеми зроблено в роботах К. Абульханової-Славської, Г. Андреєвої, Л. Божович, Б. Братуся, А. Ковальова, В. Крутецького, І. Кона, А. Матюшкіна, В. Мерліна, Б. Ломова, В. Асєєва, В. Вилюнаса, Б. Додонова, К. Волкова, Л. Фрідмана та ін.

У дослідженнях цих авторів встановлено, що ціннісні орієнтації $є$ найважливішим структурним компонентом особистості, iї «ядром», що характеризує не тільки засоби, за допомогою яких досягається мета, але й саму мету людської діяльності, більш того - його життєву позицію, ії основний зміст.

На думку цих авторів, процес становлення ціннісних орієнтацій безперервний i позв'язаний із розвитком потребнісно-мотиваційної сфери людини. Виявляються ціннісні орієнтації в ситуації вибору, у смислоутворювальній діяльності, коли вчинок не пов'язаний із нагальними завданнями, потребами, справами, а за своїм характером здатний змінювати все життя людини, її уявлення про саму себе.

Єдиної думки щодо змісту цього поняття у філософській літературі немає. Одні автори визначають його як категорію «настанова», інші - як категорії «спрямованість», «відносини». Найбільш поширеним у філософській літературі є визначення ціннісних орієнтацій особистості як поняття «відношення».

Наприклад, А. Здравомислов і В. Отрут визначають ціннісні орієнтації особистості як «найважливіше структурне утворення особистості, що виражає iï вибіркове ставлення до основних соціальних цінностей» [6].

В. Водзинський розуміє під ціннісними орієнтаціями особистості «визначену структуру ставлення особистості до фактів дійсності, конкретний вияв ставлень, що протікає у формі фіксованих настанов». 
Останнім часом проблема ціннісних орієнтацій особистості знову порушується в науковій літературі, але не стільки у філософсько-соціологічному, скільки у філософськоетичному аспекті. Це зумовлено тим напруженим процесом переоцінки цінностей, що охопив нині всі сторони громадського життя, торкнувся кожної людини. У зв'язку з цим змінився підхід до вивчення ціннісних орієнтацій особистості. Ураховуючи досягнення у вивченні питань готовності учнівської молоді до праці, професійної орієнтації, орієнтації на працю як вищу моральну цінність, багато авторів спрямовують увагу на проблему готовності особистості здійснювати свій вибір відповідно до загальнолюдських уявлень про істину, добро і красу.

Засадничими в нашому розумінні сутності категорії «ціннісні орієнтири особистості» $\epsilon$ погляди тих філософів, психологів, педагогів, що визначають іiі як структурний компонент особистості, в основі якого - система цінностей ставлення до дійсності, змістом якої $\epsilon$ усвідомлення особистістю об’єктивного блага і сприймання його як цінності. У результаті привласнене особистістю як цінність об'єктивне благо здобуває здатність регулювати і спрямовувати життєдіяльність особистості (К. Волков, О. Дробницький, А. Зосимовський, М. Казакіна, Т. Конникова, В. Мясищев, С. Рубінштейн, Л. Фрідман та ін.).

Звертаючись до визначення категорії «ціннісні орієнтири особистості», спостерігаємо, що вона містить три компоненти:

1. Пізнавальний - усвідомлення об'єктивних рис, властивостей, якостей, явищ дійсності в їхній значимості для інших людей; усвідомлення фактів дійсності в їхній значимості для себе.

2. Емоційний - переживання цінності предмета, явища, якості, факту тощо.

3. Мотивачійний - готовність діяти відповідно до прийнятого рішення в ситуації вибору.

Виокремлення кожного 3 цих структурних компонентів поняття зумовлено тими психічними процесами, що забезпечують виконання цим особистісним утворенням його ціннісно-орієнтаційної функції.

Вивчення ціннісних орієнтацій у структурі особистості вимагає розгляду їх взаємозв'язків iз самосвідомістю. Як результат усього життєвого шляху людини, самосвідомість сама стає умовою спрямованого розвитку особистості, і в цьому полягає іiі життєво важливе значення. Самосвідомість розглядається як усвідомлення людиною (дитиною) самої себе, своїх власних якостей. Особливу роль у структурі самосвідомості відіграє самооцінка. Самооцінка - це ядро особистості, важливий регулятор іiі поведінки, вона тісно пов'язана 3 рівнем домагань, впливає на оцінювання результатів діяльності, пізнання тощо [7, с. 47].

Перший учитель - найближчий і безпосередній вихователь та наставник учнів. Він організовує й спрямовує виховний процес, об'єднує виховні зусилля вчителів, батьків і суспільства, відповідає за організацію виховної роботи у своєму класі.

Здійснюючи виховний процес у класному колективі, учитель однозначно ставить за основну мету розвиток кожної особистості, формування іiі ціннісних орієнтацій 3 урахуванням вікових та індивідуальних особливостей усіх учнів.

Згідно з позицією В. Сухомлинського, людина, яка відчуває свою причетність до життя і розвитку суспільства, колективу, створює не тільки матеріальні цінності для людей вона створює саму себе.

Цінності є невід'ємними і визначальними складниками людського життя. Скільки існує людство, стільки існують й уявлення про цінності, проте предметом наукового пізнання вони стали лише в кінці XIX століття. Інтерес до цінності як предмета педагогічного дослідження виникає лише у другій половині XX століття. Для вітчизняної педагогіки поняття «цінність» як категорія педагогічного дослідження є новим i недостатньо вивченим.

О. Леонтьєв. зазначає, що «ціннісні орієнтації - це складні, певним чином згруповані принципи, які надають злагодженості різноманітним мотивам людського мислення і діяльності в ході задоволення спільних людських потреб» [8]. 
Отже, ціннісні орієнтації залежать від інтенсивності інтелектуального життя. Окрім цього, їх можна умовно поділити на два рівні: перший рівень характерезується потребою усвідомлення ціннісних позицій, які виникають не під тиском, а в ситуації вільного вибору, а також потребою вибору індивідом мети i засобів; другий рівень раціоналізовано-ідеологічний; ідеологічним рівнем є осмислення індивідом себе через призму власних цінностей, що передбачає проектування щодо себе суспільних ідей i відтворення духовного зв'язку з соціумом.

Ціннісні орієнтації формуються в ході соціалізації через проникнення інформації в індивідуально-психологічний світ індивіда. Під час первинної соціалізації набувається колективний досвід попередніх поколінь, передаються соціально схвалені стереотипи поведінки, дії, зорієнтовані на певні історично зумовлені соціокультурні цінності. Під час вторинної соціалізації набувається власний соціальний досвід, який допомагає індивіду адаптуватися в конкретному мікросередовищі, групі, колективі.

Ціннісні орієнтації особистості функціонують на основі суспільної системи цінностей, нерозривно пов'язані 3 нею, спрямовані на засвоєння і творення певних цінностей i виконують такі функції: долучають індивіда до системи, норм і цінностей соціуму; сприяють самоствердженню особистості, реалізації iï здібностей, соціальних очікувань; забезпечують гармонізацію «внутрішнього» світу особистості, систематизацію знань, норм, стереотипів.

Система ціннісних орієнтацій існує для позначення результату індивідуального відображення особистістю системи цінностей, які обрано у процесі спілкування.

Педагоги в молодших класах $є$ безпосередніми організаторами, і саме вони в процесі повсякденного життя i діяльності допомагають дітям усвідомити норми і правила поведінки.

В. Сухомлинський вважав, що необхідно не просто створювати систему цінностей, а й активно утверджувати іiі своїми діями, протистояти злу, прагнути удосконалювати суспільні відносини.

Цінності - орієнтири в надбанні людиною своєї істинної сутності, вони не існують без людей. Світ цінностей мінливий, він змінюється разом з людиною. Це - засіб життєвої орієнтації людей [1].

Інтерес до майбутньої професійної діяльності вчителя початкових класів пов'язаний з високою оцінкою суспільної значущості вчительської професії, із позитивним емоційним ставленням до неї. На наш погляд, важливого значення під час формування особистості сучасного вчителя набуває формування необхідних йому особистісних і професійних якостей, які нададуть майбутньому вчителеві можливість свідомо, із знанням справи виконувати педагогічну діяльність.

Формування професійних цінностей - це нескінченний, самодостатній процес розвитку, навчання й самоактуалізації. Тому розвиток та саморозвиток особистісних можливостей $\epsilon$ одним із головних методологічних положень функціональної моделі професійнопедагогічних цінностей у майбутніх учителів початкових класів [5].

У центрі процесу формування та розвитку особистісних та професійних цінностей сучасного вчителя початкових класів має бути вдосконалення його світогляду, який обов'язково повинен спиратися на наукове підгрунтя. Науковий світогляд виконує життєво важливі функції - пізнавальну, практичну, методологічну тощо. Він є системою наукових знань людини, її поглядів, переконань та ідеалів, у яких виражається її ставлення до розвитку природи, суспільства, свідомості, які визначають ії суспільно-політичну, морально-етичну позицію та поведінку в різних сферах життя. Тому у формуванні світогляду сучасного вчителя початкових класів важливе значення має виконання умов, які допоможуть втілювати наукові знання в систему поглядів і переконань. Насамперед це глибоке осмислення інформації. Чим глибше проникає думка вчителя в сутність наукових ідей, понять, законів, тим ширшими стають можливості для формування його поглядів і переконань. Зокрема, для перетворення знань на погляди і переконання належна 
увага має бути приділена науковому доведенню, обгрунтуванню, умінню переконувати, використовуючи педагогічну техніку та новітні технології. Адже нині вчитель перестає бути єдиним чи основним джерелом знань.

Усі ці процеси покладено в основу становлення світоглядної культури особистості, яка $\epsilon$ таким розвитком «світоглядної свідомості суб'єкта, який забезпечує: здатність особистості приймати самостійні рішення і відповідати за них; здатність до теоретичного мислення, оволодіння науковими принципами, прийомами логічного аналізу інформації; здатність і прагнення особистості до самостійних пошуків істини, навичок розв'язання суперечностей у своєму внутрішньому світі (наприклад, між особистими та суспільними інтересами); світоглядний вибір і діяльність щодо втілення світоглядних ідей і принципів у практику життя» [7, с. 136].

Всебічний розвиток особистості сучасного вчителя передбачає формування загальнолюдських норм життєдіяльності, а також добра, краси, істини, свободи та совісті, поваги, любові. За цими показниками, тобто з позицій загальнолюдської моралі, у повсякденному житті оцінюється вихованість кожного суб'єкта, передусім учителя. Адже саме він має прищеплювати ці чесноти дітям, які обов'язково порівнюватимуть усе сказане ним із поведінкою самого педагога.

Учитель повинен усвідомлювати, що адекватно пізнати себе не є простим завданням. У людині дуже багато запрограмовано природою, тому важливо знати і розуміти нахили, здібності кожної особистості, щоб допомогти її самовизначенню, самореалізації.

Задля реалізації завдань саморозвитку вчителю початкових класів необхідно акцентувати увагу на таких аспектах цього процесу, як: сприяння самовдосконаленню, самореалізації особистості; внутрішні стимули розвитку особистості (iї потреби, мотиви, інтереси та настанови); основа формування потреб, мотивів, інтересів та настанов особистості (внутрішні суперечності, які стимулюють активність особистості, сприяють іiі саморозвитку); зовнішні чинники саморозвитку особистості (впливи середовища та цілеспрямоване виховання); зовнішні умови (вони впливають на розвиток особистості не безпосередньо, не прямо, а лише виявляються у внутрішній сфері і породжують відповідні потреби, що зумовлює несхожість, різнобарвність і неповторність особистісного розвитку кожної людини, іiі індивідуальну самобутність), а в нашому випадку - це імідж сучасного вчителя початкових класів; саморозвиток особистості (це не самовільний, не спонтанний, а цілеспрямований процес); ідея саморозвитку особистості (вона повинна стати провідною в практичній діяльності школи і педагога) [4].

Отже, основними напрямами формування особистісних ціннісних орієнтацій сучасного вчителя є: поглиблення і розширення наукового світогляду вчителя; підвищення загальної культури - політичної, моральної, естетичної; постійне оновлення наукових знань, раціонального складника особистості вчителя; підвищення педагогічної майстерності; поглиблення органічного зв'язку вчителя 3 життям, соціальною практикою; утвердження активної життєвої позиції.

Учитель у школі - це втілювач ідей демократичної освіти. У цьому процесі він повинен поставати особистістю, яка втілює достатньою мірою цінності громадянського суспільства. Тому формування та розвиток особистості сучасного вчителя повинні бути першочерговим завданням професійної освіти у вищих навчальних закладах.

\section{Література}

1. Бондар Л. Виховання моральних цінностей у школярів / Л. Бондар // Початкова школа. 2000. - №12. - С. 45. 2. Державна програма «Вчитель». - К., 2002. - 30 с. 3. Державна національна програма «Освіта» («Україна XXI століття»). - К. : Райдуга, 1994. 4. Дурминенко Є. А. Саморозвиток як творення особистості / С. А. Дурминенко, Л. І. Кормиш // Педагогічний пошук. Луцьк, 1996. - № 3. - С. 19-23. 5. Жорносек І. Деякі ціннісні орієнтації молоді: [наук.-метод. зб.] / І. Жорносек. - К., 1997. - 187 с. 6. Здравомыслов А. Г. Потребности. Интересы. Ценности / Андрей Григорьевич Здравомыслов. - М. : Политиздат, 1986. - 223 с. 7. Кларин М. В. Инновационные модели обучения в зарубежных педагогических поисках / М. В. Кларин. - М. : Арена, 1994. - 290 с. 8. Леонтьев А. А. Педагогическое общение / Алексей Алексеевич Леонтьев. 
- М. : Знание, 1979. - 47 с. 9. Табачек І. В. Формування та розвиток особистості сучасного вчителя: дис. ... канд. філософ. наук: 09.00.10 / І. В. Табачек. - К., 2005. - 173 с.

УДК 372: 37.035

Н. В. Рогальська,

кандидат пед. наук, доцент,

Уманський державний педагогічний

університет імені Павла Тичини

\section{ВИКОРИСТАНННЯ МЕТОДУ ПРОЕКТІВ У ПРОФЕСІЙНІЙ ПІДГОТОВЦІ МАЙБУТНІХ ФАХІВЦІВ ДОШКІЛЬНОЇ ОСВІТИ}

Рогальська Н. В. Використання методу проектів у професійній підготовці майбутніх фахівців дошкільної освіти.

У статті розглядається проблема удосконалення професійної підготовки майбутніх фахівців дошкільної освіти, зокрема йдеться про використання у навчально-виховному процесі вищих навчальних закладів методу проектів.

Ключові слова: інноваційні технології, професійна підготовка студентів, метод проектів, дошкільна освіта.

Рогальская Н. В. Использование метода проектов в профессиональной подготовке будущих специалистов дошкольного образования.

В статье рассматривается проблема усовершенствования профессиональной подготовки будущих специалистов дошкольного образования, в частности раскрывается проблема использования в учебно-воспитательном процессе высших учебных заведений метода проектов.

Ключевые слова: инновационные технологии, профессиональная подготовка, метод проектов, дошкольное образование.

Rogalskaya N. V. Using projects in the training of future specialists preschool education.

The paper addresses the problem of improving the professional training of preschool education specialists, in particular in use in the educational process of higher education project method.

Key words: innovative technology, training students, project method, pre-school education.

Розвиток суспільства в нашій державі перебуває в тісному взаємозв'язку з необхідністю розв'язання інноваційних реформ, серед яких значну роль відіграють реформи освіти. Новий етап розвитку суспільства істотно змінює наші уявлення про мету і цінності освіти, актуалізує проблеми полікультурного виховання, акцентує на соціальній активності, громадянськості та саморозвитку особистості. У Білій книзі національної освіти України наголошується, що «кадрове» питання $\epsilon$ одним 3 головних у забезпеченні якості дошкільної освіти. Із розбудовою демократичного суспільства в нашій державі динамічно почала змінюватися освітня парадигма, підходи до забезпечення освітніх потреб суспільства, однак кадровий супровід не завжди відповідає цим запитам. Базовий компонент дошкільної освіти в Україні проголосив модернізацію змісту дошкільної освіти, впровадження в практику особистісно зорієнтованих технологій, а підготовка майбутніх спеціалістів триває за застарілими методиками. Такий підхід до формування майбутніх педагогів-дошкільників не відповідає вимогам сучасності [1]. Відтак, створення єдиного освітнього простору в межах $Є C$, орієнтація України на інтеграцію в Європейський освітній простір гостро вимагають удосконалення професійної підготовки студентів до використання педагогічних інновацій у майбутній педагогічній діяльності.

Ці проблеми можна розв'язувати, використовуючи у професійній підготовці студентів сучасний ефективний метод проектів. Питанням використання проектних технологій у навчальному процесі присвячені численні дослідження В. Безпалька, I. Булах, Б. Гершунського, Р. Кларка, О. Пєхоти, Є. Полат. Натомість використання проектного методу у професійній підготовці майбутніх дошкільних педагогів залишилося недостатньо вивченим. 